\title{
Article \\ Effects of Bovine Colostrum with or without Egg on In Vitro Bacterial-Induced Intestinal Damage with Relevance for SIBO and Infectious Diarrhea
}

\author{
Raymond J. Playford ${ }^{1,2, *}$, Naheed Choudhry ${ }^{1}$, Paul Kelly ${ }^{1}$ and Tania Marchbank ${ }^{1}$ \\ 1 Centre of Immunobiology, Blizard Institute, Barts and The London School of Medicine, Queen Mary, \\ University of London, London E1 2AT, UK; n.choudhry@qmul.ac.uk (N.C.); m.p.kelly@qmul.ac.uk (P.K.); \\ t.marchbank@qmul.ac.uk (T.M.) \\ 2 Research \& Development, Pantheryx Inc., Boulder, CO 80301, USA \\ * Correspondence: r.playford@qmul.ac.uk; Tel.: +44-2078827225
}

Citation: Playford, R.J.; Choudhry, N.; Kelly, P.; Marchbank, T. Effects of Bovine Colostrum with or without Egg on In Vitro Bacterial-Induced Intestinal Damage with Relevance for SIBO and Infectious Diarrhea. Nutrients 2021, 13, 1024. https:// doi.org/10.3390/nu13031024

Academic Editor: Elad Tako

Received: 24 February 2021

Accepted: 18 March 2021

Published: 22 March 2021

Publisher's Note: MDPI stays neutral with regard to jurisdictional claims in published maps and institutional affiliations.

Copyright: () 2021 by the authors. Licensee MDPI, Basel, Switzerland. This article is an open access article distributed under the terms and conditions of the Creative Commons Attribution (CC BY) license (https:// creativecommons.org/licenses/by/ $4.0 /)$.

\begin{abstract}
Small intestinal bacterial overgrowth (SIBO) occurs commonly, is difficult to treat, and frequently recurs. Bovine colostrum (BC) and chicken eggs contain immunoglobulins and other components that possess antimicrobial, immunoregulatory, and growth factor activities; however, it is not known if they have the ability to reduce injury caused by the presence of bacteria associated with SIBO (Streptococcus, Escherichia coli, Staphylococcus, Bacteroides, Klebsiella, Enterococcus, and Proteus) and infectious diarrhea (enteropathogenic Escherichia coli, Salmonella). We examined the effects of BC, egg, or the combination, on bacterial growth and bacteria-induced changes in transepithelial electrical resistance (TEER) and bacterial translocation across confluent Caco-2 monolayers. BC, egg, or the combination did not affect bacterial growth. Adding bacteria to monolayers reduced TEER and (with minor variations among species) increased bacterial translocation, increased monolayer apoptosis (increased caspase- 3 and $B a x \alpha$, reduced Bcl2), increased intercellular adhesion molecule 1 (ICAM-1), and reduced cell adhesion molecules zonulin1 (ZO1) and claudin-1. BC, egg, or the combination reduced these effects (all $p<0.01$ ) and caused additional increases in vascular endothelial growth factor (VEGF) and Heat Shock Protein 70 (Hsp70) expression. We conclude that BC \pm egg strengthens mucosal integrity against a battery of bacteria relevant for SIBO and for infectious diarrhea. Oral BC \pm egg may have clinical value for these conditions, especially SIBO where eradication of precipitating organisms may be difficult to achieve.
\end{abstract}

Keywords: small intestinal bacterial overgrowth (SIBO); nutraceuticals; repair; antimicrobial; irritable bowel syndrome; leaky gut

\section{Introduction}

Small intestinal bacterial overgrowth (SIBO) is defined as the presence of excess bacteria within the small intestine. Symptoms associated with SIBO include bloating, flatulence, diarrhea and abdominal discomfort [1]. Many of the clinical features are similar to those of patients with irritable bowel syndrome (IBS), although both conditions may coexist in the same patient [2]. For example, in a series of 87 adult patients presenting with chronic diarrhea, SIBO was subsequently diagnosed as the cause in half the patients, whereas IBS accounted for only 13\% [3]. Similarly, Pimental et al. reported that up to $78 \%$ of patients with a clinical diagnosis of IBS had a positive lactulose hydrogen breath test, compatible with a diagnosis of SIBO. The extent to which these patients had a "misdiagnosis" of IBS or that the two conditions coexisted in the same patients is unclear, although successful eradication of microbes with antibiotic treatment led to reduced symptoms in about half the patients [4]. Severe SIBO can manifest as malabsorption syndromes, resulting in weight loss, specific nutritional deficiencies, and more generalized complications such as osteoporosis [1]. In less developed countries, up to two-thirds of the children living 
in urban slums have documented SIBO and this has contributed to the development of environmental enteropathy and stunted growth [5].

Risk factors for development of SIBO include altered intestinal anatomy, for example, blind loop syndrome or presence of a stricture, and medical conditions such as portal hypertension, pancreatic insufficiency, chronic renal failure, hypothyroidism, Crohns' disease with small-bowel strictures, and any condition causing impaired gut motility. In support of this idea, SIBO is a frequent cause of diarrhea and malabsorption in elderly patients who have developed age-related small bowel dysmotility. Medications known to increase the risk of SIBO includes opiates (through affecting gut motility) and gastric acid suppressants such as proton pump inhibitors [1].

A mixed population of bacteria is often found in patients with SIBO, with some of the commonest species being aerobes such as Streptococcus, Escherichia coli, Staphylococcus, and Klebsiella and anaerobes such as Bacteroides, Lactobacillus, and Clostridium [1,6]. The presence of SIBO is often associated with inflammatory changes in the small bowel mucosa including blunting of the villi, atrophy of mucosa and crypts, elevation in the number of intraepithelial lymphocytes, and increased gut permeability [7], with much of the mucosal changes, at least partially, reversing if the microbes are eliminated. Currently recommended medical treatment of SIBO is with nonabsorbable antibiotics, such as rifaximin, with or without probiotics. Unfortunately, treatment with antibiotics is only effective in about $70 \%$ of patients [8] and there is a high risk of SIBO relapse in approximately $50 \%$ of cases 12 months after initial treatment [9], which requires repeated courses or continuous cyclical use of multiple antibiotics [1]. Although probiotics are sometimes advocated, they have not been conclusively shown to be beneficial and have not reached the evidential threshold to merit recommendation in the latest guidelines of the American College of Gastroenterology [10]. Therefore, novel therapies to address microbial infections and/or mitigate their effects on gut mucosa would be of value.

Currently, there is public demand for more natural types of products, in particular, when required for prolonged usage. Natural products with pharmaceutical activity are sometimes termed nutraceuticals (from nutrition and pharmaceuticals). Two nutraceutical products which have potential value for the treatment of SIBO are bovine colostrum (BC) and chicken egg, used individually or together. $\mathrm{BC}$ is the milk produced during the first few days after birth and is a rich natural source of macro- and micronutrients, growth factors, immunoglobulins (particularly $\operatorname{IgG}$ ), and peptides with antimicrobial activity (e.g., lactoperoxidase). It is produced by the milk industry and sold commercially to promote both human and veterinary general health and immune support. There is also increasing evidence that BC may be of value for the treatment of a variety of medical conditions in children and adults such as gut injury caused by nonsteroidal anti-inflammatory drugs or chemotherapy, necrotizing enterocolitis, and inflammatory bowel disease [11,12], and as a supplement for athletes to aid exercise performance and recovery [13].

Chicken eggs form an important dietary source of calories, protein, fats, and minerals. In addition to their nutritional value, eggs contain many proteins and peptides of therapeutic interest. These include antimicrobial and immunomodulatory factors such as IgY, lysozyme, avidin, ovalbumin, and ovomucoid, which suggests that egg may be a useful natural source of bioactives for clinical use [14-16]. Egg has been shown to stabilize gut mucosa against noxious agents, for example, oral egg powder has been shown to reduce DSS-induced colonic injury in mice and NSAID-induced gastric damage in rats [17]. Synergistic responses were seen when the egg and BC were used in combination in the DSS and NSAID models and in in vitro models of proliferation and migration [17]. Further evidence for the value of a BC and egg combination comes from a study performed in Guatemala that showed this combination reduced duration of diarrhea in patients with infectious diarrhea, although interpretation is limited because the study did not examine the individual components (BC and egg) in isolation [18].

To begin to examine the potential value of $\mathrm{BC}$ and/or egg to maintain mucosal integrity in patients with SIBO, we performed a series of studies that examined (1) whether 
these products had bacteriostatic/bactericidal activity against the microbes commonly seen in SIBO and against two common causes of severe infectious diarrhea, namely enteropathogenic Escherichia coli (EPEC) and Salmonella; (2) whether mucosal integrity of human intestinal cell monolayers was disrupted by the presence of these bacteria administered to the apical surfaces; (3) whether the co-presence of egg, BC, or the combination influenced the damaging effects of the bacteria on the monolayers; and (4) the molecular pathways through which any protective effects may have been mediated.

\section{Materials and Methods}

\subsection{Bovine Colostrum (BC) and Egg Samples}

The pasteurized $\mathrm{BC}$ powder $\left(45 / 15\right.$ ColostrumOne $\left.{ }^{\mathrm{TM}}\right)$ and a commercial chicken whole egg powder were provided by Pantheryx Inc. (Boulder, CO, USA). BC was collected during the first $24 \mathrm{~h}$ post calving and the subsequent powder produced was comprised of $48 \mathrm{~g}$ protein, $16 \mathrm{~g}$ fat, and $25 \mathrm{~g}$ carbohydrate per $100 \mathrm{~g}$ of powder and $15 \mathrm{~g}$ IgG/100 $\mathrm{g}$ powder. The approximate content of major growth factors (based on [19]), were as follows: insulin-like growth factor-1 (IGF-1, $133 \mathrm{ng} / \mathrm{mg}$ powder), epidermal growth factor (EGF, $14 \mathrm{ng} / \mathrm{mg}$ powder), and transforming growth factor $\beta$ (TGF $\beta, 8 \mathrm{pg} / \mathrm{mg}$ powder).

The egg powder was comprised of $51 \mathrm{~g}$ protein, $43 \mathrm{~g}$ fat, and $1 \mathrm{~g}$ carbohydrate per $100 \mathrm{~g}$ and approximately $1 \mathrm{~g} \mathrm{IgY}$ per $100 \mathrm{~g}$ egg. Ovomucoid content was approximately $50 \mathrm{mg} / \mathrm{mg}$ and ovalbumin $400 \mu \mathrm{g} / \mathrm{mg}$ powder, based on [20]. The BC and egg combination were used at a ratio of 60:40, based on the beneficial synergistic effects against DSS injury demonstrated by us previously [17].

\subsection{Cell Line}

Caco-2 is derived from the colorectal adenocarcinoma of a 72-year-old male (ATCC HTB37 ${ }^{\mathrm{TM}}$, ATCC, LGC standards, Teddington, UK). These were chosen because they are of human gastrointestinal origin and exhibit tight junctions and desmosomes between adjacent cells, therefore, they grow as polarized monolayers which can be used to perform transepithelial electrical resistance (TEER) analyses [21].

\subsection{Bacterial Strains and Culture}

Escherichia coli (E. coli, ATCC 25922 O6) and Enterococcus faecalis (ATCC 29212) were obtained from LGC Standards (Teddington, Middlesex, UK). Staphylococcus aureus (NCTC12981), Streptococcus pneumonia (NCTC 12695), Klebsiella pneumoniae (NCTC 9633), and Proteus mirabilis (NCTC 13376) Salmonella enterica subsp. enterica serovar Typhimurium (ATCC ${ }^{\circledR \circledR}$ $14028^{\mathrm{TM}}$ ) were obtained from Culture Collections (Public Health England, Porton Down, Salisbury, UK). Enteropathogenic E. coli (EPEC, ICC481-O127:H6) was a gift from Gad Frankel at Imperial College London, UK. Nonpathogenic Escherichia coli K12 were a gift from Dr David Wareham (Centre for Immunobiology, Blizard Institute, QMUL, London, UK).

Bacterial colonies were stored on Luria-Bertani (LB) agar or on Columbia agar with horse blood (blood agar, Fisher Scientific, Loughborough, UK), and fresh colonies were re-cultured weekly. Before each experiment, a single colony was cultured in LB broth and grown shaking overnight at $37^{\circ} \mathrm{C}$ followed by OD600 $\mathrm{nm}$ measurement.

\subsection{Study Series 1: Effect of BC, Egg, or the Combination on Bacterial Growth}

$\mathrm{BC}$ alone or egg alone (tested at $0.5,1,5$, and $10 \mathrm{mg} / \mathrm{mL}$ ) or $\mathrm{BC}$ with egg combination (tested at a 60:40 ratio with a final combined concentration of $0.5,1,5$, and $10 \mathrm{mg} / \mathrm{mL}$ ) were added to $1 \times 10^{6}$ colony-forming units (CFU) $/ \mathrm{mL}$ of each pathogen in LB broth for $24 \mathrm{~h}$. Following incubation, samples were serially diluted in PBS and cultured on blood agar and MacConkey agar plates (Fisher Scientific, Loughborough, UK), at $37^{\circ} \mathrm{C}$ overnight. Then, the number of colonies formed were determined. 


\subsection{Study Series 2: Effect of BC, Egg, or the Combination on Transepithelial Passage of Bacteria} and Transepithelial Electrical Resistance (TEER)

We examined the effect of $\mathrm{BC}$ alone, egg alone, or the combination treatment on pathogen-induced transepithelial permeability of confluent polarized Caco-2 monolayers, using two different, previously published, methods. One determined the change in transepithelial electrical resistance, a measure of the barrier property of the epithelium to passive ion movement, where decreased resistance indicates an increase in permeability [22]. The other analyzed bacterial translocation (determined by the number of colony-forming units obtained from medium collected from the basal side of the monolayers) [23].

Monolayers of Caco-2 polarizing colonic adenocarcinoma cells were grown to confluence in DMEM containing 10\% FCS, $4 \mathrm{mM}$ L-glutamine, $1000 \mathrm{U} / \mathrm{mL}$ penicillin, $100 \mu \mathrm{g} / \mathrm{mL}$ streptomycin, and 1\% non-essential amino acids (Invitrogen Life Technologies, Paisley, UK). Cells were grown in 24-well plates holding polyethylene terephthalate $(0.4 \mu \mathrm{m})$ cell culture inserts (transwell inserts, Millipore, Hertfordshire, UK) and grown until polarization (15-21 days). Formation and disruption of polarized monolayers (membrane integrity) were determined by daily measurement of transepithelial electrical resistance using electrodes (TER) (Millicell-ERS, Millipore, Livingston, UK). The value obtained from a blank insert (with culture medium only) was subtracted to give the net sample resistance, which was, then, multiplied by the membrane area to give the resistance in area-corrected units $\left(\Omega / \mathrm{cm}^{2}\right)$. When a consistent mean resistance of $>300 \mathrm{Ohms} / \mathrm{cm}^{2}$ was obtained (approximately 15-20 days), monolayers were washed three times in medium without antibiotics. Then, $\mathrm{BC}$ alone $(1 \mathrm{mg} / \mathrm{mL})$, egg alone $(1 \mathrm{mg} / \mathrm{mL})$, or $\mathrm{BC}+\mathrm{egg}$ combination treatments $(0.6 \mathrm{mg} / \mathrm{mL} \mathrm{BC}+0.4 \mathrm{mg} / \mathrm{mL}$ egg $)$ and bacteria $\left(1 \times 10^{6} \mathrm{CFU} /\right.$ well $)$ were added to the apical surface in culture media without antibiotics or FCS. TEER was measured just prior to addition of bacteria + test products and $24 \mathrm{~h}$ later. Bacterial translocation was determined by culturing medium from the basolateral compartment of a transwell insert, after infection for colony quantification for $24 \mathrm{~h}$. Measurements were taken from 6 wells per treatment, results are expressed as mean \pm SEM.

\subsection{Study Series 3: Mechanisms of Action of BC, Egg, or the Combination for Maintaining Epithelial Integrity}

Having shown that $\mathrm{BC}$, egg, or combination products reduced monolayer permeability, cleared lysates from in vitro monolayer studies were analyzed to examine possible modes of action.

\subsubsection{Cell Lysate Preparation}

Following incubation with bacteria $\pm \mathrm{BC}$, egg, or the combination, cells were washed in ice-cold PBS, lysed in lysis buffer (50 mM HEPES, $5 \mathrm{mM}$ DTT, $0.1 \mathrm{mM}$ EDTA, $0.1 \%$ CHAPS, $\mathrm{pH}$ 7.4) for $5 \mathrm{~min}$ on ice. Lysates were cleared by centrifugation at $10,000 \times g$ for $10 \mathrm{~min}$ at $4{ }^{\circ} \mathrm{C}$. Protein concentrations were determined by a standard BCA method (Pierce).

\subsubsection{Tight Junction Proteins}

ZO1 and claudin- 1 concentrations were determined using previously published methods [24] and standard ELISA kits (Generon, Slough, UK)

\subsubsection{Cell Apoptosis Assays}

Active caspase-3 was determined, using methods described previously [24], using commercial colorimetric assay kits (BF3100, R\&D Systems, Minneapolis, MN, USA). Concentrations of the anti-apoptotic protein $\mathrm{Bcl} 2$ and the proapoptotic protein Bax $\alpha$ were determined in the same cell lysates as used for caspase analyses, using Duoset Elisa kits (R\&D Systems Europe Ltd., Abingdon, UK). 


\subsubsection{ICAM-1, VEGF, and Hsp70}

ICAM-1, VEGF, and Hsp70 concentrations in the cleared cell lysates was determined using Duoset Elisa kits, as per the manufacturer's instructions (R\&D Systems Europe Ltd., Abingdon, UK).

\subsection{Statistical Analyses}

All results are expressed as mean \pm SEM. Statistics were performed using Graphpad Prism 8 version 8.3.1. The test for normality of data, the Shapiro-Wilks test, was performed and showed equal variances among products. Results were analyzed using a one-way repeated measures analysis of variance (ANOVA). Comparisons between treatments was performed using a Tukey's multiple comparison test.

\section{Results}

\subsection{Study Series 1: Effect of BC, Egg or the Combination on Bacterial Growth}

Treatment with BC, egg, or the combination did not influence proliferation of any of the bacteria at any of the concentrations tested (Table S1).

\subsection{Study Series 2: Effect of BC, Egg, or the Combination on Transepithelial Passage of Bacteria and TEER}

\subsubsection{Bacterial Translocation}

Figure 1 demonstrates the effects of $\mathrm{BC}$, egg, or the combination on the amount of bacterial translocation across the monolayers for the eight bacteria associated with SIBO or infectious diarrhea.
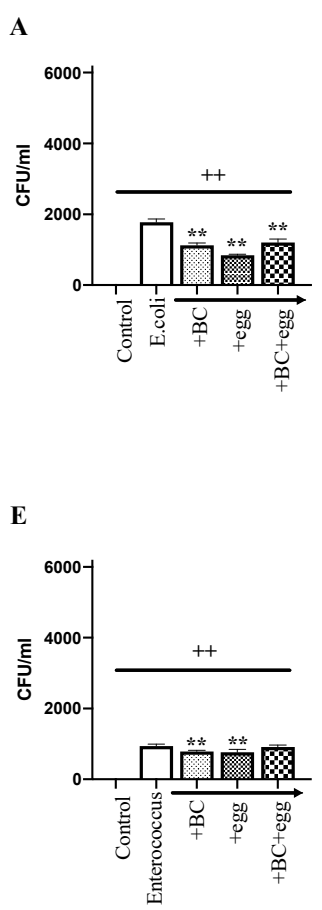

B

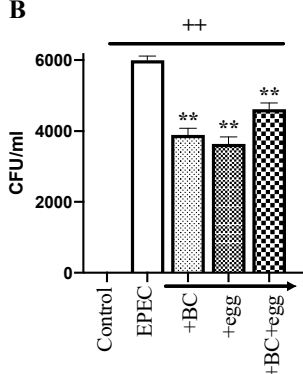

$\mathbf{F}$



C

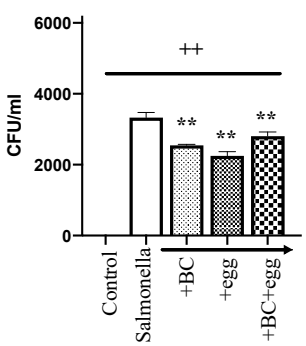

G

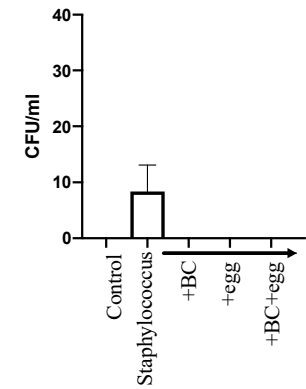

D

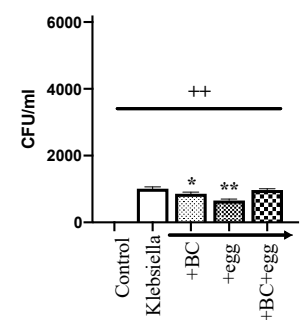

H

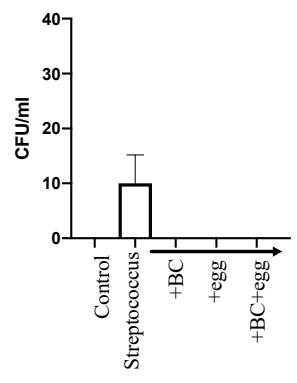

Figure 1. Effect of bovine colostrum (BC), egg, or the combination on transepithelial passage of bacteria. Bacterial strains $\left(1 \times 10^{6}\right.$ colony-forming units $(\mathrm{CFU}) /$ well $) \pm \mathrm{BC}(1 \mathrm{mg} / \mathrm{mL})$, egg $(1 \mathrm{mg} / \mathrm{mL})$, or the combination $(0.6 \mathrm{mg} / \mathrm{mL} \mathrm{BC}$ $+0.4 \mathrm{mg} / \mathrm{mL}$ egg) were added to the apical side of confluent monolayers of Caco-2 cells grown in transwell plates. The medium was collected from the basal side, $24 \mathrm{~h}$ later, and assessed for the number of colony-forming units (CFU)/mL. Control wells received no bacteria or test product. (A) Escherichia coli ATCC 25922 O6; (B) enteropathogenic E. coli (EPEC); (C) Salmonella; (D) Klebsiella; (E) Enterococcus; (F) Proteus; (G) Staphylococcus; (H) Streptococcus. Note that the scale of the $y$-axis of results for Staphylococcus and Streptococcus are lower than for other strains. Results are expressed as mean \pm SEM for 6 wells. ++ signifies $p<0.01$ vs. non treated (without bacteria or test product) control, ${ }^{*}$ and ${ }^{* *}$ signify $p<0.05$ and 0.01 vs. bacteria alone. The nonpathogenic and noninvasive E. coli $\mathrm{K} 12 \mathrm{did}$ not result in any CFUs in this experiment, and therefore is not shown. 
The nonpathogenic Escherichia coli K12 (noninvasive negative control) did not translocate across the monolayer (or affect TEER or any of the other measured parameters). All other strains caused bacterial translocation through the monolayer into the basal medium, with the co-presence of $\mathrm{BC}$, egg, or the combination significantly reducing the number of bacteria subsequently isolated from the basal medium (Figure 1). The highest levels of translocation were seen using EPEC. Lower levels of translocation were seen when testing Staphylococcus and Streptococcus, with the co-presence of test products completely preventing their translocation (Figure 1).

\subsubsection{TEER}

Figure 2A demonstrates the effects of BC, egg, or the combination on E. coli ATCC 25922 O6 induced changes in TEER. The other measured parameters using this bacterium are also shown in Figure 2B-F as an exemplar, so that inter-related mechanisms (such as TEER and tight junction proteins for mucosal integrity, caspase-3, Bax $\alpha$, and Bcl2 for apoptosis) can be seen easier. As similar findings were found using the other bacteria, their results are presented in Tables 1-3 and Figures 3-5 and differences to E. coli ATCC 25922 O6 noted by exception within the text.

Table 1. Effects of BC alone, egg, or the combination on bacteria-induced changes in TEER and tight junction protein ZO1.

\begin{tabular}{|c|c|c|c|c|}
\hline & +Bacteria & Bacteria + BC & Bacteria + Egg & Bacteria + BC + Egg \\
\hline \multicolumn{5}{|c|}{ TEER $\left(\mathrm{Ohm} / \mathrm{cm}^{2}\right)$ Baseline without bacteria control value $=346 \pm 5.9$} \\
\hline E. coli $\mathrm{K} 12$ (-ve control) & $336 \pm 10$ & $353 \pm 7$ & $374 \pm 12$ & $356 \pm 11$ \\
\hline EPEC & $167 \pm 6++$ & $201 \pm 3++* *$ & $220 \pm 2++* *$ & $195 \pm 5++* *$ \\
\hline Salmonella & $173 \pm 2++$ & $197 \pm 6++* *$ & $229.5 \pm 4++* *$ & $186 \pm 1++* *$ \\
\hline Klebsiella & $236 \pm 10++$ & $230 \pm 6++$ & $259 \pm 1++* *$ & $216 \pm 9++$ \\
\hline Enterococcus & $219 \pm 3++$ & $219 \pm 5++$ & $231 \pm 2++* *$ & $220 \pm 2++$ \\
\hline Proteus & $213 \pm 8++$ & $227 \pm 2++$ & $229.8 \pm 1++$ & $223 \pm 1++$ \\
\hline Staphylococcus & $281 \pm 5++$ & $306 \pm 14++$ & $325 \pm 6.8^{* *}$ & $291 \pm 3++$ \\
\hline Streptococcus & $279 \pm 6++$ & $326 \pm 16^{*}$ & $323 \pm 19 *$ & $290 \pm 3++$ \\
\hline \multicolumn{5}{|c|}{ 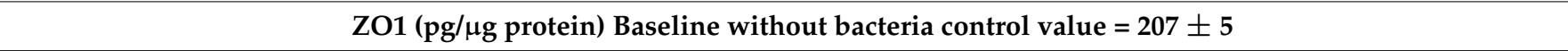 } \\
\hline E. coli $\mathrm{K} 12$ & $206 \pm 3.5$ & $205 \pm 3$ & $206 \pm 1$ & $204 \pm 1$ \\
\hline EPEC & $156 \pm 6++$ & $205 \pm 1++* *$ & $201 \pm 2++* *$ & $183 \pm 3++* *$ \\
\hline Salmonella & $177 \pm 8++$ & $205 \pm 2++* *$ & $201 \pm 2++^{* *}$ & $171 \pm 27++$ \\
\hline Klebsiella & $151 \pm 1++$ & $175 \pm 0.5++* *$ & $163 \pm 4++* *$ & $153 \pm 2++$ \\
\hline Enterococcus & $71 \pm 21.5++$ & $190 \pm 2++* *$ & $183 \pm 0.1++* *$ & $175 \pm 3++* *$ \\
\hline Proteus & $95 \pm 1++$ & $146 \pm 1++^{* *}$ & $132 \pm 5++* *$ & $133 \pm 4++* *$ \\
\hline Staphylococcus & $161 \pm 2++$ & $162 \pm 1++$ & $171 \pm 1++$ & $155 \pm 30++$ \\
\hline Streptococcus & $173 \pm 1++$ & $156 \pm 5++$ & $175 \pm 1++$ & $165 \pm 28++$ \\
\hline
\end{tabular}

Bacterial strains $\pm \mathrm{BC}$, egg, or the combination were added to apical side of confluent Caco-2 monolayers; $1 \mathrm{mg} / \mathrm{mL}$ of $\mathrm{BC}$ alone, $1 \mathrm{mg} / \mathrm{mL}$ egg alone or $0.6 \mathrm{mg} / \mathrm{mL} \mathrm{BC}+0.4 \mathrm{mg} / \mathrm{mL}$ egg were used. Then, $24 \mathrm{~h}$ later, TEER changes were assessed and Caco-2 cell lysates were analyzed for ZO1. Results expressed as mean \pm SEM from 3 wells. ++ signifies $p<0.01$ vs. non treated (without bacteria or test product) control and * \&** signify $p<0.05 \& 0.01$ vs. bacteria alone. E. coli $\mathrm{K} 12$ is nonpathogenic and noninvasive and used as a negative control.

The presence of $\mathrm{BC}$, egg, or the combination without bacteria did not affect TEER. Similarly, noninvasive Escherichia coli K12 did not affect TEER. The addition of E. coli ATCC $25922 \mathrm{O} 6$ caused a $42 \%$ reduction in TEER (Figure $2 \mathrm{~A}$ ) and this reduction was truncated by about $23 \%$ adding $\mathrm{BC}$ alone, $32 \%$ using egg alone and $16 \%$ using $\mathrm{BC}$ and egg combination (Figure 2A). All other bacterial strains resulted in a similar fall in TEER to using E. coli ATCC 25922 O6 (average reduction $133 \pm 15.8 \mathrm{Ohms} / \mathrm{cm}^{2}$, Table 1). Co-presence of BC alone significantly truncated the fall in TEER when tested against EPEC, Salmonella, and Streptococcus (Table 1). The addition of egg alone also truncated the reduction in TEER caused by Enterococcus, Klebsiella, Staphylococcus, and Streptococcus (Table 1). No additional benefit was seen using the combination. 
A

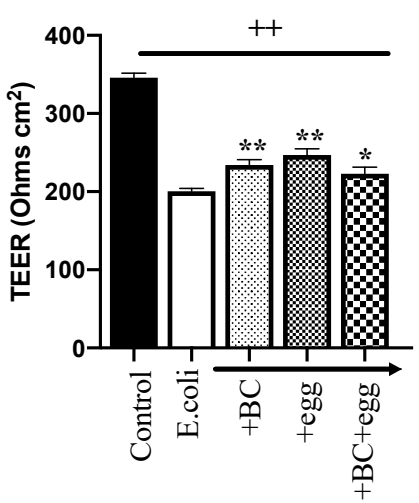

D



G

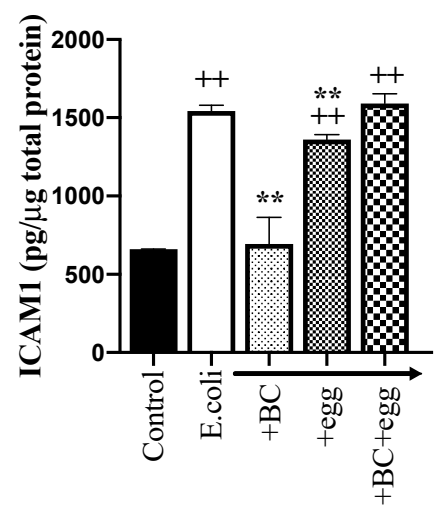

B

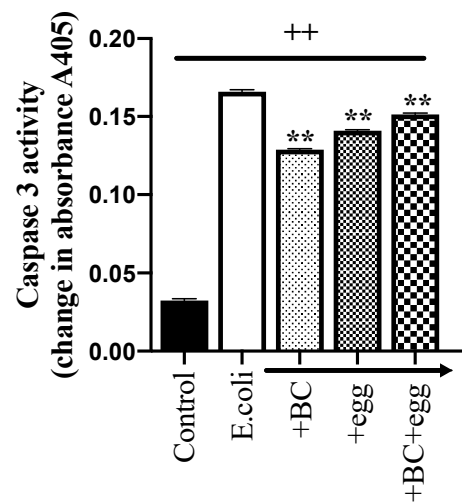

$\mathbf{E}$

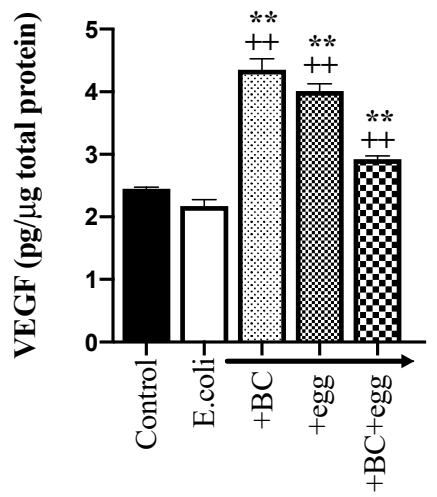

H

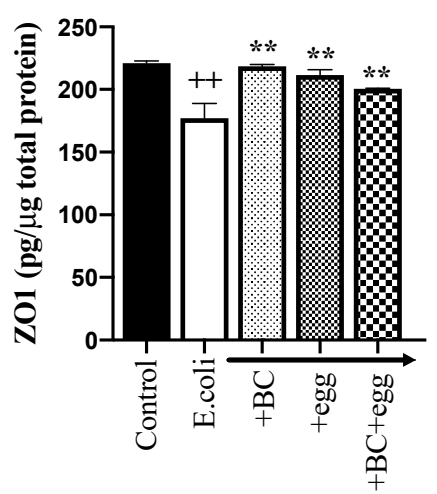

C

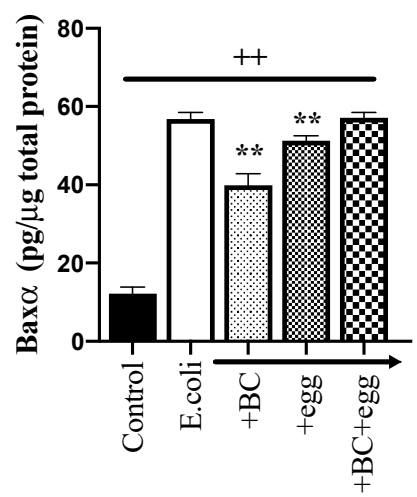

F

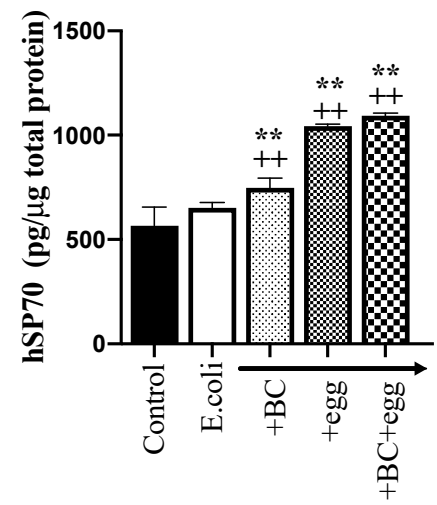

I

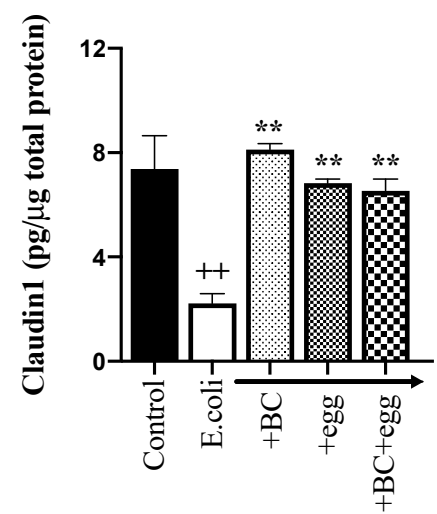

Figure 2. Effect of Escherichia coli ATCC 25922 O6 on Caco-2 monolayer TEER and damaging and repair pathways in the presence of $\mathrm{BC}$, egg, or the combination. E. coli $\left(1 \times 10^{6} \mathrm{CFU} /\right.$ well $) \pm \mathrm{BC}$, egg, or the combination was added to confluent Caco-2 cells; $1 \mathrm{mg} / \mathrm{mL}$ of BC alone, $1 \mathrm{mg} / \mathrm{mL}$ egg alone or $0.6 \mathrm{mg} / \mathrm{mL} \mathrm{BC}+0.4 \mathrm{mg} / \mathrm{mL}$ egg were used. Changes in TEER (A) were determined $24 \mathrm{~h}$ later. Following incubation, cleared cell lysates were collected and changes in caspase-3 (B), $\operatorname{Bax} \alpha(\mathbf{C}), \operatorname{Bcl} 2$ (D), VEGF (E), Hsp70 (F), ICAM-1 (G), ZO1 (H), and claudin-1 (I) were determined. Results expressed as mean \pm SEM for 6 wells. ++ signifies $p<0.01$ vs. non treated (without bacteria or test product) control, ${ }^{*}$ and ${ }^{* *}$ signify $p<0.05$ and 0.01 vs. presence of bacteria alone. The other bacterial strains tested gave similar results (Tables $1-3)$.and are noted by exception in the text. 
Table 2. Effect of BC alone, egg, or the combination on bacteria-induced changes in apoptosis signaling molecules.

\begin{tabular}{|c|c|c|c|c|}
\hline & +Bacteria & Bacteria + BC & Bacteria + Egg & Bacteria + BC + Egg \\
\hline \multicolumn{5}{|c|}{ Bax $\alpha(\mathrm{pg} / \mu \mathrm{g}$ protein) Baseline without bacteria control value $=12.17 \pm 1.67$} \\
\hline E. coli $\mathrm{K} 12$ & $14.2 \pm 1.67$ & $12.8 \pm 2$ & $14.67 \pm 1.5$ & $12.3 \pm 1.5$ \\
\hline EPEC & $49.8 \pm 0.33++$ & $36.7 \pm 1.17++* *$ & $36.5 \pm 0.33++* *$ & $44.3 \pm 1.16++* *$ \\
\hline Salmonella & $44.3 \pm 1.17++$ & $36.5 \pm 1++* *$ & $36.5 \pm 1++* *$ & $44 \pm 0.5++$ \\
\hline Klebsiella & $63.3 \pm 1.17++$ & $61.2 \pm 1.33++$ & $63.5 \pm 1.76++$ & $63.8 \pm 3++$ \\
\hline Enterococcus & $67 \pm 0.83++$ & $37.7 \pm 0.83++* *$ & $39.3 \pm 2.5++* *$ & $46.2 \pm 2.3++{ }^{* *}$ \\
\hline Proteus & $66 \pm 0.17++$ & $58.8 \pm 0.33++* *$ & $59.7 \pm 0.5++* *$ & $64.7 \pm 0.8++$ \\
\hline Staphylococcus & $55.3 \pm 0.83++$ & $39.2 \pm 1++* *$ & $45.8 \pm 2.7++* *$ & $53.3 \pm 3.5++$ \\
\hline Streptococcus & $66.8 \pm 0.33++$ & $64.5 \pm 3.3++$ & $73.6 \pm 2.7++$ & $69.3 \pm 1.17++$ \\
\hline \multicolumn{5}{|c|}{$\mathrm{Bcl} 2(\mathrm{pg} / \mu \mathrm{g}$ protein) Baseline without bacteria control value $=61.5 \pm 0.87$} \\
\hline E. coli $\mathrm{K} 12$ & $59.5 \pm 0.3$ & $61.5 \pm 0.3$ & $54.2 \pm 1.7$ & $56 \pm 5.2$ \\
\hline EPEC & $45 \pm 4++$ & $61.5 \pm 0.9^{* *}$ & $69.5 \pm 1.4++* *$ & $53 \pm 2.9++* *$ \\
\hline Salmonella & $38 \pm 4.6++$ & $59.5 \pm 0.9^{* *}$ & $57 \pm 3.5^{* *}$ & $54 \pm 5.2^{* *}$ \\
\hline Klebsiella & $66 \pm 3.5$ & $55 \pm 2.6$ & $61.5 \pm 2$ & $57 \pm 0.6$ \\
\hline Enterococcus & $37.5 \pm 0.9++$ & $36 \pm 0.6++$ & $38.5 \pm 3.2++$ & $35 \pm 3.5++$ \\
\hline Proteus & $31.5 \pm 0.3++$ & $61.5 \pm 0.3^{* *}$ & $53 \pm 4^{* *}$ & $67 \pm 3.5^{* *}$ \\
\hline Staphylococcus & $54 \pm 7.5$ & $62 \pm 5.8$ & $72.5 \pm 3.7++*$ & $79.5 \pm 6.6++* *$ \\
\hline Streptococcus & $63 \pm 3.5$ & $51.5 \pm 2.6$ & $66.5 \pm 0.9++* *$ & $81.8 \pm 2.2++* *$ \\
\hline
\end{tabular}

Same experiment as Table 1, i.e., $1 \mathrm{mg} / \mathrm{mL}$ of BC alone, $1 \mathrm{mg} / \mathrm{mL}$ egg alone, or $0.6 \mathrm{mg} / \mathrm{mL} \mathrm{BC}+0.4 \mathrm{mg} / \mathrm{mL}$ egg were used. Results are expressed as mean \pm SEM from 3 wells. ++ signifies $p<0.01$ vs. non treated (without bacteria or test product) control and ${ }^{*}$ or ${ }^{* *}$ signifies $p<0.05$ or $p<0.01$ vs. bacteria alone, respectively. E. coli K12 is nonpathogenic and noninvasive and used as a negative control.

Table 3. Effect of BC alone, egg, or the combination on damaging effect of bacterial strains on VEGF and Hsp70.

\begin{tabular}{|c|c|c|c|c|}
\hline & + Bacteria & Bacteria + BC & Bacteria + Egg & Bacteria + BC + Egg \\
\hline \multicolumn{5}{|c|}{ VEGF (pg/ $\mu$ g protein) Baseline without bacteria control value $=2.45 \pm 0.03$} \\
\hline E. coli $\mathrm{K} 12$ & $2.67 \pm 0.55$ & $2.57 \pm 0.004$ & $2.56 \pm 0.01$ & $2.79 \pm 0.24$ \\
\hline EPEC & $2.52 \pm 0.05$ & $3.72 \pm 0.03++* *$ & $3.49 \pm 0.01++^{* *}$ & $3.41 \pm 0.04++* *$ \\
\hline Salmonella & $4.4 \pm 0.03++$ & $5.56 \pm 0.01++* *$ & $5.2 \pm 0.02++* *$ & $4.5 \pm 0.07++* *$ \\
\hline Klebsiella & $2.31 \pm 0.36$ & $2.57 \pm 0.3$ & $2.62 \pm 0.27$ & $3.59 \pm 0.26++* *$ \\
\hline Enterococcus & $5.11 \pm 0.14++$ & $5.48 \pm 0.15++* *$ & $5 \pm 0.2++$ & $4.8 \pm 0.01++$ \\
\hline Proteus & $3.16 \pm 0.01++$ & $3.69 \pm 0.14++* *$ & $3.21 \pm 0.19++$ & $3.15 \pm 0.01++$ \\
\hline Staphylococcus & $4.51 \pm 0.06++$ & $4.59 \pm 0.11++$ & $4.53 \pm 0.04++$ & $4.29 \pm 0.29++$ \\
\hline Streptococcus & $4.96 \pm 0.04++$ & $4.58 \pm 0.12++$ & $4.46 \pm 0.01++$ & $4.75 \pm 0.18++$ \\
\hline \multicolumn{5}{|c|}{ Hsp70 (pg/ $\mu$ g protein) Baseline without bacteria control value $=566 \pm 90$} \\
\hline E. coli $\mathrm{K} 12$ & $675 \pm 57$ & $682 \pm 30$ & $694 \pm 72$ & $677 \pm 65$ \\
\hline EPEC & $492 \pm 60$ & $867 \pm 87++* *$ & $792 \pm 40++* *$ & $782 \pm 4++* *$ \\
\hline Salmonella & $642 \pm 40$ & $966 \pm 12++* *$ & $1091 \pm 23++* *$ & $923 \pm 119++* *$ \\
\hline Klebsiella & $1396 \pm 10++$ & $1167 \pm 25++$ & $1422 \pm 28++$ & $1234 \pm 2++$ \\
\hline Enterococcus & $1195 \pm 129++$ & $1589 \pm 15++* *$ & $1599 \pm 67++* *$ & $1425 \pm 5++* *$ \\
\hline Proteus & $860 \pm 28++$ & $1083 \pm 27++* *$ & $1135 \pm 11++* *$ & $963 \pm 21++* *$ \\
\hline Staphylococcus & $1172 \pm 82++$ & $1165 \pm 185++$ & $1031 \pm 101++$ & $1185 \pm 147++$ \\
\hline Streptococcus & $1280 \pm 86++$ & $1540 \pm 10++* *$ & $1333 \pm 97++$ & $1157 \pm 235++$ \\
\hline
\end{tabular}

$1 \mathrm{mg} / \mathrm{mL}$ of BC alone, $1 \mathrm{mg} / \mathrm{mL}$ egg alone, or $0.6 \mathrm{mg} / \mathrm{mL} \mathrm{BC}+0.4 \mathrm{mg} / \mathrm{mL}$ egg were tested. Results are expressed as mean \pm SEM from 3 wells. ++ signifies $p<0.01$ vs. non treated (without bacteria or test product) control and ${ }^{* *}$ signifies $p<0.01$ vs. bacteria alone. 


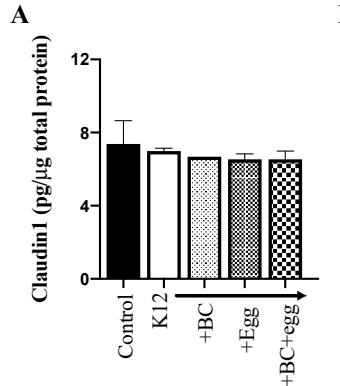

$\mathbf{E}$

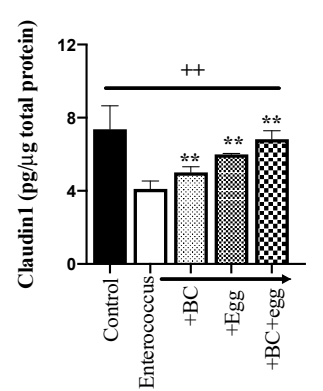

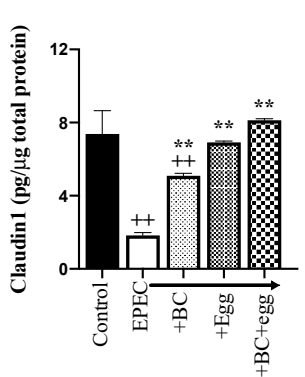

$\mathbf{F}$

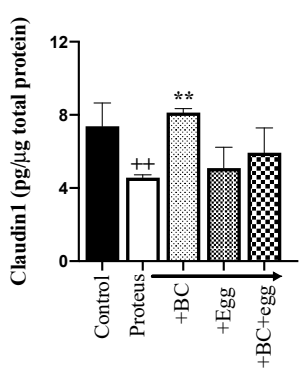

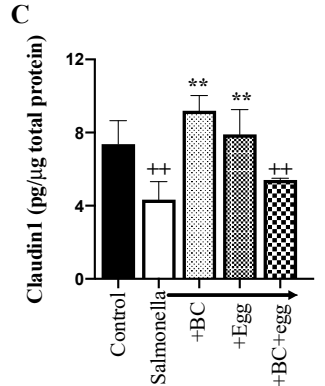

$\mathbf{G}$

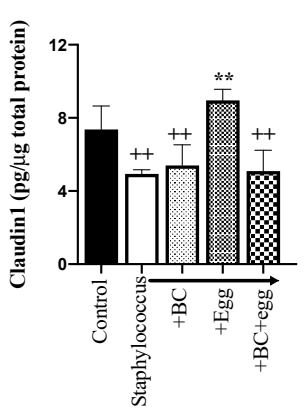

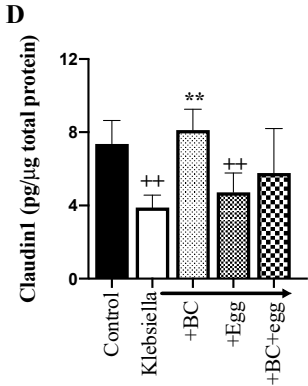

$\mathbf{H}$

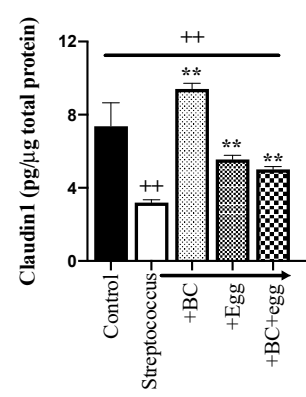

Figure 3. Effect of $B C$, egg, or the combination on tight junction protein, claudin-1. Bacterial strains $\left(1 \times 10^{6} \mathrm{CFU} /\right.$ well $)$ $\pm \mathrm{BC}(1 \mathrm{mg} / \mathrm{mL})$, egg $(1 \mathrm{mg} / \mathrm{mL})$, or the combination $(0.6 \mathrm{mg} / \mathrm{mL} \mathrm{BC}+0.4 \mathrm{mg} / \mathrm{mL}$ egg $)$ were added to confluent monolayers of Caco-2 cells. Cleared lysates were prepared $24 \mathrm{~h}$ later. Control wells received no bacteria or test product. (A) Escherichia coli K12 (negative control); (B) EPEC; (C) Salmonella; (D) Klebsiella; (E) Enterococcus; (F) Proteus; (G) Staphylococcus; (H) Streptococcus. Results are expressed as mean \pm SEM from 3 wells. ++ signifies $p<0.01$ vs. non treated (without bacteria or test product) control and ${ }^{* *}$ signifies $p<0.01$ vs. bacteria alone.



$\mathbf{E}$

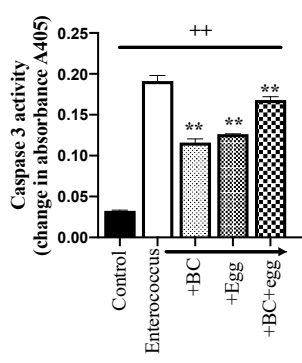

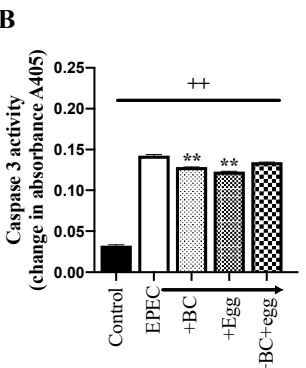

$\mathbf{F}$

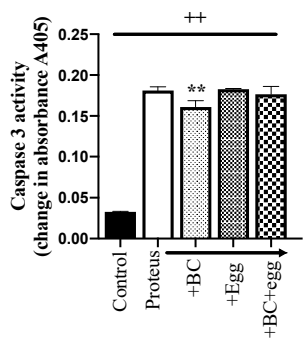

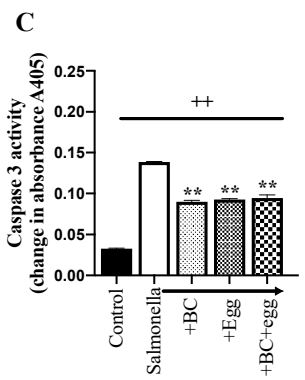

G

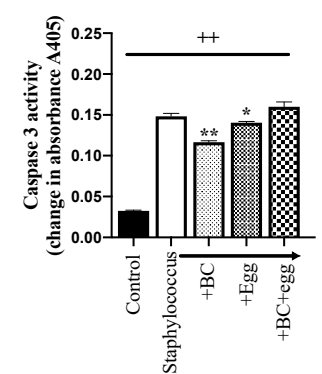

D

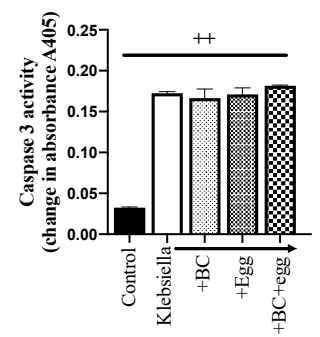

H

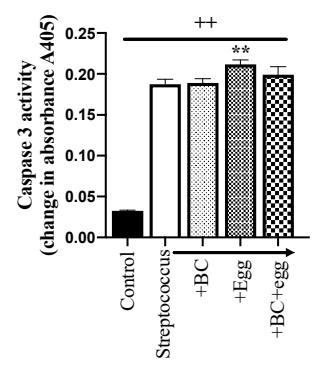

Figure 4. Effect of $B C$, egg, or the combination on active caspase-3. Bacterial strains $\left(1 \times 10^{6} \mathrm{CFU} / \mathrm{well}\right) \pm \mathrm{BC}(1 \mathrm{mg} / \mathrm{mL})$, egg $(1 \mathrm{mg} / \mathrm{mL})$, or the combination $(0.6 \mathrm{mg} / \mathrm{mL}$ BC $+0.4 \mathrm{mg} / \mathrm{mL}$ egg) were added to confluent monolayers of Caco-2 cells. Cleared lysates were prepared $24 \mathrm{~h}$ later. Control wells received no bacteria or test product. (A) E. coli K12 (negative control); (B) EPEC; (C) Salmonella; (D) Klebsiella; (E) Enterococcus; (F) Proteus; (G) Staphylococcus; (H) Streptococcus. Results are expressed as mean \pm SEM from 3 wells. ++ signifies $p<0.01$ vs. non treated (without bacteria or test product) control and * \& ** signify $p<0.05 \& 0.01$ vs. bacteria alone. 
A

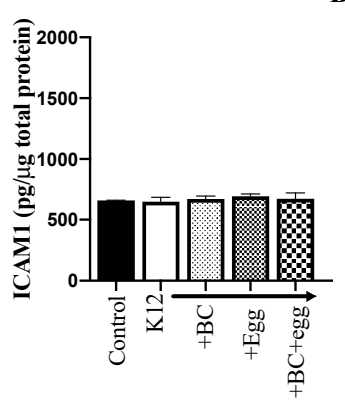

E

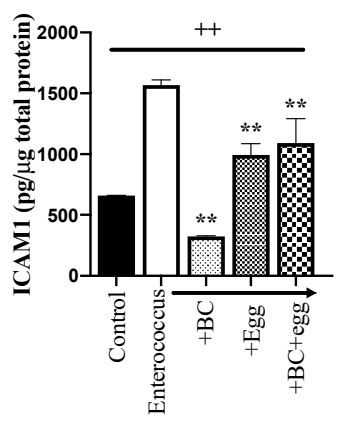

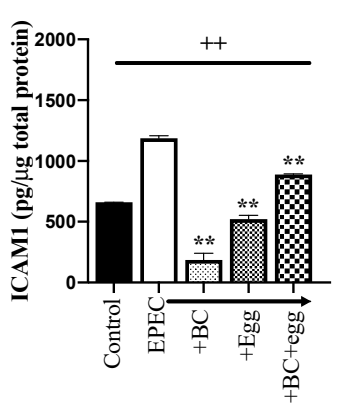

F

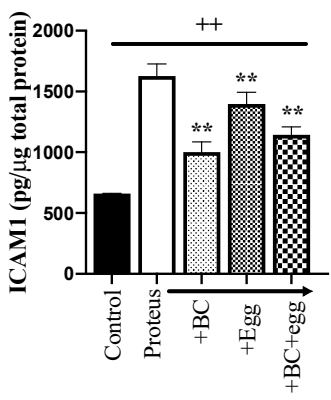

C

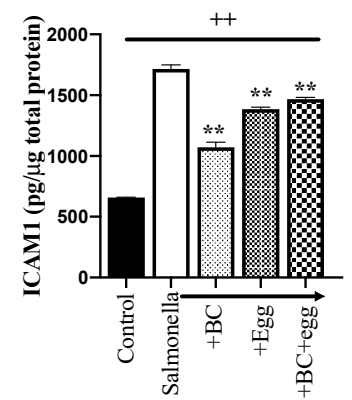

G

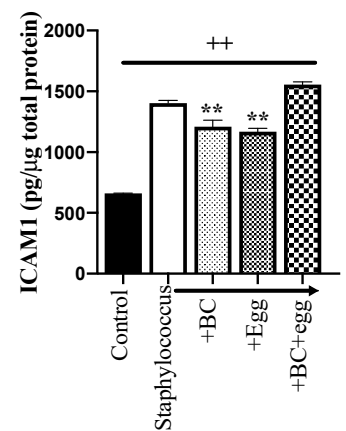

D

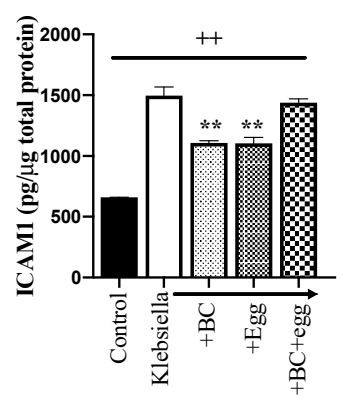

H

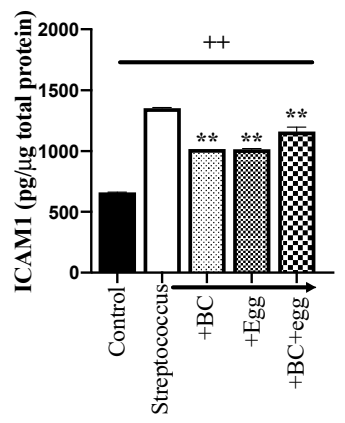

Figure 5. Effect of BC, egg, or the combination on ICAM-1. Bacterial strains $\left(1 \times 10^{6} \mathrm{CFU} /\right.$ well $) \pm \mathrm{BC}(1 \mathrm{mg} / \mathrm{mL})$, egg $(1 \mathrm{mg} / \mathrm{mL})$, or the combination $(0.6 \mathrm{mg} / \mathrm{mL} \mathrm{BC}+0.4 \mathrm{mg} / \mathrm{mL}$ egg) were added to confluent monolayers of Caco-2 cells. Cleared lysates were prepared $24 \mathrm{~h}$ later. Control wells received no bacteria or test product. (A) E. coli K12 (negative control); (B) EPEC; (C) Salmonella; (D) Klebsiella; (E) Enterococcus; (F) Proteus; (G) Staphylococcus; (H) Streptococcus. Results are expressed as mean \pm SEM from 3 wells. ++ signifies $p<0.01$ vs. non treated (without bacteria or test product) control and ${ }^{* *}$ signifies $p<0.01$ vs. bacteria alone.

\subsection{Study Series 3: Mechanisms of Action of BC, Egg, or the Combination for Maintaining Epithelial Integrity}

\subsubsection{Tight Junction Proteins}

Claudin and ZO1, which are both tight junction proteins, reduced in response to the presence of all bacteria tested (except K12 negative control). The presence of BC truncated the fall in ZO1 in all strains except for Staphylococcus and Streptococcus and truncated the fall in claudin in all strains except for Staphylococcus. Similar effects were seen with egg alone or the combination (Figure 2H,I and Figure 3 and Table 1).

\subsubsection{Cell Apoptosis Assays}

All bacteria strains (except negative control K12) increased active caspase-3 (Figures 2B and 4), with a mean increase of $0.133 \pm 0.007$ change in absorbance A405. The co-presence of BC truncated this increase for all strains except for Klebsiella and Streptococcus. No additional benefits were seen using either egg alone or the combination.

The proapoptotic molecule Bax $\alpha$ increased in response to all bacteria (except K12). As with caspase-3, the addition of BC alone truncated this increase for all strains, except for Klebsiella and Streptococcus. No additional benefits were seen using either egg alone or the combination (Figure 2C and Table 2)

Anti-apoptotic $\mathrm{Bcl} 2$ levels decreased in response to bacteria except for Klebsiella and Streptococcus, with BC causing similar reciprocal trends in truncation to the effects on caspase-3 and Bax $\alpha$ (Figure 2D and Table 2). 


\subsubsection{ICAM-1, VEGF, and Hsp70}

Expression of ICAM-1 increased in response to presence of all bacteria tested. BC or egg alone reduced ICAM-1 expression for all bacterial strains (Figures 2G and 5).

The presence of most of the tested bacterial strains (E. coli, EPEC, Salmonella, Enterococcus, Proteus, Staphylococcus, and Streptococcus), resulted in increased VEGF expression. $B C$, egg, or the combination further increased VEGF levels in most of the bacterial strains (E. coli, EPEC, Salmonella, Enterococcus, Proteus, and Klebsiella) (Figure 2E and Table 3).

Hsp70 levels increased in response to the presence of bacteria for most of the strains tested with BC or egg, causing further increases except for Klebsiella and Staphylococcus (Figure $2 \mathrm{~F}$ and Table 3). Additional benefits were not seen using the combination.

\section{Discussion}

$\mathrm{BC}$ and egg both contain multiple antimicrobial and immunomodulatory components essential for host development and defense functions. The major form of immunoglobulin in $B C$ is $\operatorname{IgG}(>80 \%$ of total IgG content), with lower amounts of IgA and IgM [25]. BC contains many cytokines of relevance for immune modulation and cellular responses to stressors such as bacterial infection; these cytokines include TNF $\alpha, \mathrm{GMCSF}$, and interleukin (IL)-1 $\beta,-6$, and -10 . BC also contains over twenty different peptide growth factors including EGF and TGF $\alpha$, members of the TGF $\beta$ family, IGF, PDGF, and milk fat globule epidermal growth factor. Oligosaccharides and glycoproteins in BC may also be relevant in reducing binding of bacteria to epithelial cells through acting as competitive inhibitors by mimicking epithelial cell surface carbohydrates. For a recent detailed review of $B C$ and its constituents see [25].

Similarly, egg contains multiple components of potential biological relevance within the egg white and yolk. Proteins with antimicrobial activity include avian beta-defensin, avidin, beta-microseminoprotein-like, cystatin, gallin immunoglobulin $Y$, lysozyme, ovalbumin, ovoglobulinG2/TENP, ovoinhibitor, ovomucin, ovotransferrin, phosvitin, pleiotrophin, and vitelline membrane outer layer protein 1 . Several of these proteins, such as ovotransferrin, ovomucoid, ovomucin hydrolysates, and phosvitin also act as antioxidants. Multiple factors with immune modulatory activity, such as lysozyme and pleiotrophin, have also been identified. In addition, sulfated glycopeptides generated by proteolysis from ovomucin, chalazae, and yolk membrane can stimulate macrophage function and partial digestion of ovotransferrin, and vitellogenin may generate immune modulatory compounds. For a detailed review of the constituents and biological activity of egg see [14].

Passive immunity is predominantly produced by the $\operatorname{IgG}$ content in $\mathrm{BC}$ and by $\operatorname{Ig} \mathrm{Y}$ in egg. Immunization of cows and chickens results in hyperimmune IgG and IgY which have been shown to benefit conditions such as rotavirus infection $[16,26]$. However, it is important to note that non-hyperimmune "standard" BC or egg also contains IgG/Y directed against a wide spectrum of bacteria relevant for gut health including Klebsiella, Salmonella pseudomonas, Staphylococci, and E. coli, due to the cows' and chickens' natural exposure [27-30]. The BC used in the current study was collected during the first $24 \mathrm{~h}$ post calving, since there is a rapid decline in IgG and other bioactive components after this time [19].

The bacteria tested in the current series of experiments covered the most common aerobic organisms cultured from patients with SIBO. In addition, we included two more toxic bacteria associated with episodic diarrhea, i.e., EPEC and Salmonella, to determine if common protective mechanisms were present across bacteria with differing toxicity and because a $\mathrm{BC}$ and egg combination had been reported to reduce diarrhea caused by these organisms [18]. The addition of $\mathrm{BC}$, egg, or the combination did not inhibit growth of the bacteria in vitro, which were results in keeping with previous findings that hyperimmune IgY antibodies raised against 078:K80 E coli. only inhibited bacterial growth when added at extremely high concentrations $(150 \mathrm{mg} / \mathrm{mL})$ [30]. However, this does not mean the $\mathrm{IgG}$ and IgY antibodies (or other antimicrobial factors) are irrelevant in vivo. For example, IgG and IgY may have bound to the bacterial cell walls, but as these studies were performed 
in vitro, the immune effector cells normally present in vivo would not have progressed the microbial killing process. In addition, Igs may have also mediated some of the beneficial effects of $\mathrm{BC}$ and egg in the monolayer experiments by reducing adherence of bacteria to the colonic cells and/or reducing translocation through the monolayers by causing bacterial "clumping" through cross linking.

To test the effects of $B C$ alone and egg alone we used $1 \mathrm{mg} / \mathrm{mL}$, and we used the same final concentration for the combination (i.e., $1 \mathrm{mg} / \mathrm{mL}$ total, comprising $0.6 \mathrm{mg} / \mathrm{mL} \mathrm{BC}$ with $0.4 \mathrm{mg} / \mathrm{mL}$ of egg) to examine if synergy occurred with the combination product. We had previously shown that $1 \mathrm{mg} / \mathrm{mL}$ was the optimal concentration for $\mathrm{BC}$ or egg for inducing proliferation and migration in a variety of gut cell lines including Caco-2 cells, without causing any toxic effects [17]. Similarly, the 60:40 BC/egg ratio was used as it had been shown to reduce duration of diarrhea in patients with infectious diarrhea [18] and we previously showed synergistic responses when used in this ratio for reducing DSS-induced colitis and NSAID-induced small intestinal injury [17].

Our findings that the noninvasive K12 did not result in changes in TEER, translocation, or any of the other markers established that the findings using the other bacteria were not simply due to a generic "bacterial presence" effect. The co-addition of BC \pm egg with E. coli $\mathrm{K} 12$ also did not affect any of the measured parameters, which was in agreement with our previous findings that BC added to "non-stressed" colonic HT29 cells did not affect caspase-3, Bax $\alpha$, and Bcl2 levels or affect TEER [24]. When all the other bacteria were assessed, each strain caused a similar fall in TEER. In contrast, there was wide range in the amount of bacterial translocation across the monolayers, which was dependent on the strain tested. Therefore, there are advantages in using more than one method to determine change in mucosal integrity in response to bacterial stress. Beneficial effects of $B C$ alone, or egg alone, were demonstrated using both methods of assessment. Although no synergistic advantage was seen using the $\mathrm{BC}$ and egg combination in this in vitro model, this may be because it did not contain the multiplicity of immune cells present in vivo. SIBO is associated with small intestinal inflammatory changes [7] and our previous in vivo studies have shown synergistic anti-inflammatory reparative effects using the combination for reducing both small intestinal and colonic injury [17].

Intestinal epithelial tight junctions are multiprotein complexes that act as selective barriers. There are at least 40 different proteins composing the tight junctions, consisting of both transmembrane and cytoplasmic proteins. We measured claudin- 1 as an example of a major transmembrane protein (further notable members being occludin and claudins) and also measured changes in ZO1 which is located on the intracellular side of plasma membrane and anchors the strands to the actin component of the cytoskeleton. The reduction in ZO1 and claudin-1 levels in response to bacterial administration is likely relevant to an explanation for the lowered intestinal integrity and increased permeability of the monolayers. Our finding that $\mathrm{BC} \pm$ egg truncated these changes may, therefore, have contributed to the enhanced integrity and improvement in TEER.

Increased apoptosis occurred in response to all bacterial strains, with the increase in the pro-apoptotic $\mathrm{Bax} \alpha$, and reduction in anti-apoptotic Bcl-2 signaling molecules, probably contributing to this response. Our finding that $B C \pm$ egg reversed changes in $B a x \alpha$ and $\mathrm{Bcl} 2$ suggests this pathway is important in mediating their protective effects.

Hsp70 is a protein that protects against excessive against apoptosis [31] and has overlapping protective effects with VEGF which reduces apoptosis, stimulates angiogenesis, and causes immune modulation [32]. These proteins both increased in response to the presence of most of the bacteria tested, with further increases in expression if $\mathrm{BC} \pm \mathrm{egg}$ was co-present, suggesting that (in bacteria where this occurred) stimulation of Hsp70 and VEGF expression may have relevance to the protective effects of $B C \pm$ egg.

For all measured parameters, there were variations in the degree of response dependent on the bacterial strain used, or when $\mathrm{BC} \pm$ egg was added. This is unsurprising given that the processes by which the bacterial strain interacts/injures the epithelium vary depending on the bacteria being assessed. For example, Klebsiella did not cause a rise in 
VEGF when added on its own, or when the combination, $\mathrm{BC} \pm \mathrm{egg}$, was present. A detailed examination of why these differences occur goes beyond the scope of this manuscript, but it is notable that Klebsiella translocate across gut monolayers via transcellular processes, as opposed to the normal paracellular pathways used by other strains [33]. As a further example of variations in mechanisms of action among strains, S. aureus releases alpha-toxin which binds to surface receptors on target cells causing formation of transmembrane pores, resulting in increased cytosolic calcium levels, with the toxins also causing downregulation of tight junction proteins including ZO1 [34].

ICAM-1 stabilizes cell-cell interactions and facilitates leukocyte endothelial transmigration. Its upregulation in cells in response to the presence of bacteria would result in increased leukocyte infiltration in vivo but was not be directly demonstrated in the in vitro model used. Our finding that BC \pm egg reduced ICAM-1 expression could potentially have beneficial effects if reproduced in the in vivo situation.

Nutraceuticals, also known as functional foods, are products derived from food sources that provide extra health benefits, in addition to their basic nutritional value. Pharmaceuticals usually involve a single chemical molecule which can be directly held responsible for the pharmacological actions they induce. The identification of the relevant compound(s) in nutraceuticals is more difficult as they are less refined and contain multiple potentially important components. However, provided that robust scientific studies are performed, their biological (and clinical) significance remains valid. There is significant consumer interest for such products, due in part to concerns over the risks and side effects of pharmaceutical agents. BC provides a strong example of an evidence-based nutraceutical with over 6000 preclinical and clinical studies having been published. The public perceive BC as the comprehensive "superfood", linking it to nature's first food from breastfeeding, with the added advantage of limiting its own digestion when taken orally.

Our previous studies on bioactive components of BC and egg suggest that for both products, the EGFR pathways is important for mediating many of their protective activities. Examples involving gastrointestinal cell lines include the findings that the protective effect of BC against heat-induced apoptosis, and the pro-proliferative and migratory activity of egg were all reduced if an EGFR blocker was administered [17,24]. In addition, EGF induces changes in the composition of tight junctions through activating several signaling pathways such as PKC, MAPK, and STATs. For a detailed review see Tang et al. [35].

TGF $\beta$ is also an important molecule for mediating the promigratory activity of BC or egg on gut cell lines $[17,19]$ and is involved in multiple homeostatic pathways including cell motility, immune responses, and mucosal integrity [36]. Further studies would be required to determine the contribution of individual components present in $\mathrm{BC}$ and egg that mediate these effects, although the situation is more complex in vivo, as cells are simultaneously exposed to multiple factors that can result in synergistic responses. For example, when bovine lactoferrin and EGF (both present in BC) were added together to rat intestinal IEC-18 cells, it resulted in a synergistic growth response [37].

In conclusion, using an in vitro model, our studies showed $\mathrm{BC} \pm$ egg strengthened mucosal integrity against a battery of bacteria relevant for SIBO and for infectious diarrhea. Actions included reducing bacterial translocation and apoptosis and enhancing Hsp70 and cell adhesion molecules. These studies support the potential value of $\mathrm{BC} \pm \mathrm{egg}$ for the treatment of these conditions and may have particular value for SIBO where definitive eradication of precipitating organisms may be difficult to achieve. They may also be relevant in explaining the protective effect of $\mathrm{BC} \pm$ egg against NSAID-induced small intestinal injury [17], where induction of intestinal dysbiosis plays an important role in its pathogenesis [38]. Clinical studies comprising $\mathrm{BC} \pm$ egg given alone or in combination with probiotics (as oligosaccharides and glycoproteins in BC also possess prebiotic activity [25]), or with other factors to enhance activity, appear warranted.

Supplementary Materials: The following are available online at https:/ / www.mdpi.com/2072-664 3/13/3/1024/s1, Table S1. Effect of BC, egg, or the combination on bacterial growth. 
Author Contributions: Conceptualization, R.J.P., P.K., N.C. and T.M.; methodology, R.J.P., P.K., N.C. and T.M.; validation, R.J.P., N.C. and T.M.; formal analysis, R.J.P. and T.M.; investigational resources, R.J.P. and P.K.; data curation, R.J.P. and T.M.; writing-original draft preparation, R.J.P. and T.M.; writing-review and editing, R.J.P., T.M., N.C. and P.K.; project administration, T.M.; funding acquisition, R.J.P. and P.K. All authors have read and agreed to the published version of the manuscript.

Funding: This study was partially funded by PanTheryx Inc. The funder provided support in the form of salaries for R.J.P. and provided partial funding for T.M. in her role as an external consultant and a research grant support for N.C. PanTheryx did not have any additional role in the study design, data collection and analysis, decision to publish, or preparation of the manuscript.

Institutional Review Board Statement: No human or animal subjects were used in these experiments.

Informed Consent Statement: No human subjects were used in these experiments.

Data Availability Statement: Articles are licensed under an open access Creative Commons CC BY 4.0 license, meaning that anyone may download and read the paper for free.

Conflicts of Interest: PanTheryx Inc. supply BC to the USA, European, and Asia-Pacific markets and are also the producers of DiaResQ ${ }^{\mathrm{TM}}$, a bovine colostrum and egg combination. Data included in this publication form part of the U.S. provisional patent application U.S. 62/978,104 in which R.J.P., N.C., and P.K. are named inventors. This does not affect our adherence to the Nutrients policies regarding sharing data and materials.

$\begin{array}{ll}\text { Abbreviations } \\ \text { ANOVA } & \text { Analysis of variance } \\ \text { BC } & \text { Bovine colostrum } \\ \text { EGF } & \text { Epidermal growth factor } \\ \text { EPEC } & \text { Enteropathogenic Escherichia coli } \\ \text { IGF } & \text { Insulin-like growth factor } \\ \text { SIBO } & \text { Small intestinal bacterial overgrowth } \\ \text { TEER } & \text { Transepithelial electrical resistance } \\ \text { TGF } & \text { Transforming growth factor }\end{array}$

\section{References}

1. Middleton, S.J.; Playford, R.J. Bacterial overgrowth of the small intestine. In Oxford Textbook of Medicine, 6th ed.; Oxford University Press: Oxford, UK, 2020; pp. 2879-2883.

2. Ghoshal, U.C.; Shukla, R.; Ghoshal, U. Small Intestinal Bacterial Overgrowth and Irritable Bowel Syndrome: A Bridge between Functional Organic Dichotomy. Gut Liver 2017, 11, 196-208. [CrossRef] [PubMed]

3. Dukowicz, A.C.; Lacy, B.E.; Levine, G.M. Small intestinal bacterial overgrowth: A comprehensive review. Gastroenterol. Hepatol. 2007, 3, 112-122.

4. Pimentel, M.; Chow, E.J.; Lin, H.C. Eradication of small intestinal bacterial overgrowth reduces symptoms of irritable bowel syndrome. Am. J. Gastroenterol. 2000, 95, 3503-3506. [CrossRef]

5. Mello, C.S.; Rodrigues, M.S.D.C.; Filho, H.B.D.A.; Melli, L.C.F.L.; Tahan, S.; Pignatari, A.C.C.; De Morais, M.B. Fecal microbiota analysis of children with small intestinal bacterial overgrowth among residents of an urban slum in Brazil. J. Pediatr. 2018, 94, 483-490. [CrossRef] [PubMed]

6. Jacobs, C.; Adame, E.C.; Attaluri, A.; Valestin, J.; Rao, S.S.C. Dysmotility and proton pump inhibitor use are independent risk factors for small intestinal bacterial and/or fungal overgrowth. Aliment. Pharmacol. Ther. 2013, 37, 1103-1111. [CrossRef] [PubMed]

7. Haboubi, N.Y.; Lee, G.S.; Montgomery, R.D. Duodenal Mucosal Morphometry of Elderly Patients with Small Intestinal Bacterial Overgrowth: Response to Antibiotic Treatment. Age Ageing 1991, 20, 29-32. [CrossRef]

8. Gatta, L.; Scarpignato, C. Systematic review with meta-analysis: Rifaximin is effective and safe for the treatment of small intestine bacterial overgrowth. Aliment. Pharmacol. Ther. 2017, 45, 604-616. [CrossRef] [PubMed]

9. Lauritano, E.C.; Gabrielli, M.; Scarpellini, E.; Lupascu, A.; Novi, M.; Sottili, S.; Vitale, G.; Cesario, V.; Serricchio, M.; Cammarota, G.; et al. Small Intestinal Bacterial Overgrowth Recurrence After Antibiotic Therapy. Am. J. Gastroenterol. 2008, 103, $2031-2035$. [CrossRef]

10. Pimentel, M.; Saad, R.J.; Long, M.D.; Rao, S.S.C. ACG Clinical Guideline: Small Intestinal Bacterial Overgrowth. Am. J. Gastroenterol. 2020, 115, 165-178. [CrossRef] 
11. Panahi, Y.; Falahi, G.; Falahpour, M.; Moharamzad, Y.; Khorasgani, M.R.; Beiraghdar, F.; Naghizadeh, M.M. Bovine Colostrum in the Management of Nonorganic Failure to Thrive: A Randomized Clinical Trial. J. Pediatr. Gastroenterol. Nutr. 2010, 50, 551-554. [CrossRef] [PubMed]

12. Playford, R.J.; Macdonald, C.E.; Calnan, D.P.; Floyd, D.N.; Podas, T.; Johnson, W.; Wicks, A.C.; Bashir, O.; Marchbank, T. Coadministration of the health food supplement, bovine colostrum, reduces the acute non-steroidal anti-inflammatory drug-induced increase in intestinal permeability. Clin. Sci. 2001, 100, 627-633. [CrossRef]

13. Buckley, J.D.; Brinkworth, G.D.; Abbott, M.J. Effect of bovine colostrum on anaerobic exercise performance and plasma insu-linlike growth factor I. J. Sports Sci. 2003, 21, 577-588. [CrossRef]

14. Réhault-Godbert, S.; Guyot, N.; Nys, Y. The Golden Egg: Nutritional Value, Bioactivities, and Emerging Benefits for Human Health. Nutrients 2019, 11, 684. [CrossRef]

15. Kovacs-Nolan, J.; Phillips, M.; Mine, Y. Advances in the Value of Eggs and Egg Components for Human Health. J. Agric. Food Chem. 2005, 53, 8421-8431. [CrossRef] [PubMed]

16. Wang, X.; Song, L.; Tan, W.; Zhao, W. Clinical efficacy of oral immunoglobulin Y in infant rotavirus enteritis: Systematic re-view and meta-analysis. Medicine 2019, 98, e16100. [CrossRef]

17. Playford, R.J.; Garbowsky, M.; Marchbank, T. Pasteurized Chicken Egg Powder Stimulates Proliferation and Migration of AGS, RIE1, and Caco-2 Cells and Reduces NSAID-Induced Injury in Mice and Colitis in Rats. J. Nutr. 2020, 150, 1434-1442. [CrossRef]

18. Gaensbauer, J.T.; Melgar, M.A.; Calvimontes, D.M.; Lamb, M.M.; Asturias, E.J.; Contreras-Roldan, I.L.; Dominguez, S.R.; Robinson, C.C.; Berman, S. Efficacy of a bovine colostrum and egg-based intervention in acute childhood diarrhoea in Guatemala: A randomised, double-blind, placebo-controlled trial. BMJ Glob. Health 2017, 2, e000452. [CrossRef]

19. Playford, R.J.; Cattell, M.; Marchbank, T. Marked variability in bioactivity between commercially available bovine colostrum for human use; implications for clinical trials. PLOS ONE 2020, 15, e0234719, Erratum in 2020, 15, e0240392.

20. Lee, J.; Paik, H.-D. Anticancer and immunomodulatory activity of egg proteins and peptides: A review. Poult. Sci. 2019, 98, 6505-6516. [CrossRef]

21. Fogh, J.; Fogh, J.M.; Orfeo, T. One Hundred and Twenty-Seven Cultured Human Tumor Cell Lines Producing Tumors in Nude Mice23. J. Natl. Cancer Inst. 1977, 59, 221-226. [CrossRef] [PubMed]

22. Srinivasan, B.; Kolli, A.R.; Esch, M.B.; Abaci, H.E.; Shuler, M.L.; Hickman, J.J. TEER Measurement Techniques for In Vitro Barrier Model Systems. J. Lab. Autom. 2015, 20, 107-126. [CrossRef] [PubMed]

23. Choudhry, N.; Scott, F.; Edgar, M.; Sanger, G.J.; Kelly, P. Reversal of Pathogen-Induced Barrier Defects in Intestinal Epithelial Cells by Contra-pathogenicity Agents. Dig. Dis. Sci. 2021, 66, 88-104. [CrossRef]

24. Marchbank, T.; Davison, G.; Oakes, J.R.; Ghatei, M.A.; Patterson, M.; Moyer, M.P.; Playford, R.J. The nutriceutical bovine colostrum truncates the increase in gut permeability caused by heavy exercise in athletes. Am. J. Physiol. Liver Physiol. 2011, 300, G477-G484. [CrossRef]

25. Playford, R.; Weiser, M. Bovine Colostrum: Its Constituents and Uses. Nutrients 2021, 13, 265. [CrossRef]

26. Ebina, T.; Ohta, M.; Kanamaru, Y.; Yamamoto-Osumi, Y.; Baba, K. Passive immunizations of suckling mice and infants with bovine colostrum containing antibodies to human rotavirus. J. Med. Virol. 1992, 38, 117-123. [CrossRef]

27. Rump, J.; Arndt, R.; Arnold, A.; Bendick, C.; Dichtelmüller, H.; Franke, M.; Helm, E.; Jäger, H.; Kampmann, B.; Kolb, P.; et al. Treatment of diarrhoea in human immunodeficiency virus-infected patients with immunoglobulins from bovine colostrum. $J$. Mol. Med. 1992, 70, 588-594. [CrossRef] [PubMed]

28. Brooks, H.J.; McConnell, M.A.; Corbett, J.; Buchan, G.S.; Fitzpatrick, C.E.; Broadbent, R.S. Potential prophylactic value of bovine colostrum in necrotizing enterocolitis in neonates: An in vitro study on bacterial attachment, antibody levels and cytokine production. FEMS Immunol. Med. Microbiol. 2006, 48, 347-354. [CrossRef] [PubMed]

29. Lissner, R.; Thürmann, P.A.; Merz, G.; Karch, H. Antibody reactivity and fecal recovery of bovine immunoglobulins follow-ing oral administration of a colostrum concentrate from cows (Lactobin) to healthy volunteers. Int. J. Clin. Pharmacol. Ther. 1998, 36, 239-245. [PubMed]

30. Mahdavi, A.; Rahmani, H.; Nili, N.; Samie, A.; Soleimania, S. Chicken Egg Yolk Antibody (IgY) Powder Against Escherichia coli O78:K80. J. Anim. Veter Adv. 2010, 9, 366-373. [CrossRef]

31. Rokutan, K. Role of heat shock proteins in gastric mucosal protection. J. Gastroenterol. Hepatol. 2000, 15, 12-19. [CrossRef]

32. Duffy, A.M.; Bouchier-Hayes, D.J.; Harmey, J.H. Vascular Endothelial Growth Factor (VEGF) and Its Role in Non-Endothelial Cells: Autocrine Signalling by VEGF. In Madame Curie Bioscience Database; Landes Bioscience: Austin, TX, USA, 2004 ; pp. 133-144.

33. Hsu, C.-R.; Chang, I.-W.; Hsieh, P.-F.; Lin, T.-L.; Liu, P.-Y.; Huang, C.-H.; Li, K.-T.; Wang, J.-T. A Novel Role for the Klebsiella pneumoniae Sap (Sensitivity to Antimicrobial Peptides) Transporter in Intestinal Cell Interactions, Innate Immune Responses, Liver Abscess, and Virulence. J. Infect. Dis. 2019, 219, 1294-1306. [CrossRef] [PubMed]

34. Kwak, Y.-K.; Vikström, E.; Magnusson, K.-E.; Vécsey-Semjén, B.; Colque-Navarro, P.; Möllby, R. The Staphylococcus aureus Alpha-Toxin Perturbs the Barrier Function in Caco-2 Epithelial Cell Monolayers by Altering Junctional Integrity. Infect. Immun. 2012, 80, 1670-1680. [CrossRef]

35. Tang, X.; Liu, H.; Yang, S.; Li, Z.; Zhong, J.; Fang, R. Epidermal Growth Factor and Intestinal Barrier Function. Mediat. Inflamm. 2016, 2016, 1-9. [CrossRef] [PubMed]

36. McEntee, C.P.; Gunaltay, S.; Travis, M.A. Regulation of barrier immunity and homeostasis by integrin-mediated transforming growth factor $\beta$ activation. Immunology 2019, 160, 139-148. [CrossRef] [PubMed] 
37. Hagiwara, T.; Shinoda, I.; Fukuwatari, Y.; Shimamura, S. Effects of Lactoferrin and Its Peptides on Proliferation of Rat Intestinal Epithelial Cell Line, IEC-18, in the Presence of Epidermal Growth Factor. Biosci. Biotechnol. Biochem. 1995, 59, $1875-1881$. [CrossRef] [PubMed]

38. Otani, K.; Tanigawa, T.; Watanabe, T.; Shimada, S.; Nadatani, Y.; Nagami, Y.; Tanaka, F.; Kamata, N.; Yamagami, H.; Shiba, M.; et al. Microbiota Plays a Key Role in Non-Steroidal Anti-Inflammatory Drug-Induced Small Intestinal Damage. Digestion 2017, 95, 22-28. [CrossRef] [PubMed] 